\title{
PENGARUH STRUKTUR KEPEMILIKAN TERHADAP PEMILIHAN AUDITOR PADA PERUSAHAAN YANG TERDAFTAR DI BURSA EFEK INDONESIA
}

\author{
Ivone* dan Noorasyikin* \\ *Program Studi Akuntansi, Fakultas Ekonomi \\ Universitas Internasional Batam \\ Email: ivone.chen@uib.ac.id; noorasyi@gmail.com
}

\begin{abstract}
Good financial governance is developed into a balancing system to minimize the presence of inappropriate information in the financial statements. As one of the external mechanisms of corporate governance, external audit plays an important role in strengthening the trust and financial information of the company in terms of providing an independent check on financial information provided by management. The ownership structure of the company can be a factor in selecting an audit company based on the desired quality measurement. Focusing on Indonesia, this study used a sample of 429 companies listed on the Indonesia Stock Exchange during 2014-2018. The data used in the form of annual reports and company financial statements published in general in official sources. Testing assumptions and data analysis are completed by the logistic regression method. The findings obtained from the test are the presence of concentrated ownership and foreign ownership in the company may have significant positive effect on the selection of auditors but for controlling family ownership has the opposite result, namely negative relationship, and no significant effect on managerial ownership of the elected auditor.
\end{abstract}

Keywords: auditor selection, ownership structure, audit quality

\section{PENDAHULUAN}

Struktur kepemilikan pada perusahaan memberikan beberapa motivasi untuk mengamati dengan baik pelaporan keuangan serta melihat pengaruh dari auditor independen. Hall, Hoffman, dan Liu (2017) menuturkan, bahwa salah satu motivasi perusahaan tersebut dalam melaksanakan audit eksternal ialah menjadikan laporan keuangan yang sudah diaudit sebagai informasi utama terkait nilai kemampuan perusahaan dan investor secara signifikan dalam menyelidiki informasi akuntansi dan pembuatan ketetapan putusan keuangan.

Yuniarti (2011) menuturkan bahwa auditor eksternal sebagai salah satu cara kerja tata kelola perusahaan mempunyai tujuan untuk memastikan laporan keuangan yang dihasilkan andal, dimana menurut PSAK 1 (2018) laporan keuangan yang baik ialah laporan pencatatan yang secara jelas menyajikan penjelasan terkait posisi keuangan dan kemampuan keuangan perusahaan secara terstruktur guna melengkapi kebutuhan informasi pengguna laporan keuangan tahunan tersebut.

\section{KAJIAN LITERATUR DAN PENGEMBANGAN HIPOTESIS}

2.1 Pemilihan Auditor

Dibutuhkannya laporan keuangan perusahaan sebagai pemberi keyakinan bagi para investor, pemilihan auditor berkualitas tinggi juga digunakan untuk mengurangi tingkat permasalahan yang terjadi pada perusahaan. Semakin besar ukuran dan tingkat kompleksitas sebuah perusahaan maka kebutuhan dalam memilih auditor berkualitas tinggi juga semakin besar (Trisnawati, 2015). Sejalan dengan itu, Knechel, Niemi, dan Sundgren (2005) menuturkan skema dalam audit dapat memberikan keuntungan bagi perusahaan dengan peningkatan yang terjadi atas efektivitas dan efisiensi, kepatuhan 
terhadap peraturan yang berlaku, serta mengurangi masalah asimetri informasi dan dapat mengurangi kemungkinan perusahaan dalam melakukan fraud.

Ketika menentukan pilihan terkait keterlibatan auditor ekternal pada perusahaan, penelitian rumit telah dilakukan demi memilih auditor spesifik mana yang akan dipekerjakan. Dalam pemilihan auditor, Revier dan Schroé (2010) mengatakan perusahaan akan mengutamakan pertimbangan mereka akan tingkat kualitas tertentu dalam memantau pelayanan auditor eksternal. Pada penelitian Farooq dan Tabine (2015), juga menuturkan kepentingan reputasi pada auditor meningkatkan banyaknya perusahaan gulung tikar yang diakibatkan oleh peningkatan kendala agensi dan penurunan dari pengungkapan informasi. Menurutnya, perusahaan terbuka di negara perekonomian berkembang memiliki lebih banyak masalah agensi daripada perusahaan tertutup dikarenakan adanya pemisahan antara manajemen dan pemegang saham eksternal, hal inilah yang mendorong peneliti dalam mengumpulkan data tentang penentu auditor eksternal pilihan mereka.

\subsubsection{Pengaruh Konsentrasi Kepemilikan Terhadap Pemilihan Auditor}

Maksud utama dari penelitian yang dikerjakan oleh Zeng (2013) yakni guna menyelidiki relasi antara tata kelola perusahaan dan pilihan auditor. Dengan ini konsentrasi kepemilikan, independensi dan aktivitas dari dewan direksi, serta komite audit memberikan dampak signifikan positif pada pemilihan auditor. Selain itu penelitian lainnya seperti yang dilaksanakan oleh Kolsi, Makni, dan Affes (2012) pada industri di Tunisia, menyiratkan bahwa kehadiran mayoritas pengendali atau pemegang saham memiliki efek positif pada kualitas audit. Dalam penelitiannya juga dikatakan bahwa pemegang saham mayoritas lebih menyukai pilihan auditor berkualitas lebih tinggi untuk melakukan kontrol yang efektif terhadap manajer guna meningkatkan kualitas informasi yang disiapkan oleh mereka. Selain itu, auditor berkualitas lebih tinggi merupakan penjamin tambahan untuk keandalan pelaporan keuangan. Dwekat dan Mardawi (2017) yang dalam penelitiannya menggunakan sampel perusahaan yang tercatat di Bursa Palestina juga menemukan bahwa adanya pengaruh positif antara konsentrasi kepemilikan dengan kualitas audit.

H1: Konsentrasi kepemilikan mempunyai pengaruh signifikan positif terhadap pemilihan auditor.

\subsubsection{Pengaruh Kontrol Keluarga Terhadap Pemilihan Auditor}

Pada literatur teori agensi menunjukkan bahwa meningkatkan persentase kepemilikan pemegang saham keluarga akan mengurangi konflik keagenan (Mahdavi, Maharlouie, Ebrahimi, \& Sarikhani, 2011). Dari beberapa penelitian yang dilaksanakan, contoh oleh Chrisman, Chua, dan Litz (2004), menunjukkan bahwa masalah keagenan dalam entitas keluarga lebih baik daripada di entitas non-keluarga (Niskanen, Karjalainen, \& Niskanen, 2011). Menurut Corten, Steijvers, dan Lybaert (2017), representasi anggota non-keluarga di perusahaan sebagai indikator konflik kepemimpinan antara keluarga dan nonkeluarga dikemukakan secara positif berkaitan langsung dengan pemilihan auditor. Berbeda dengan Ho dan Kang (2013), yang dalam penelitiannya memeriksa pemilihan auditor dan biaya audit di perusahaan keluarga, beranggapan bahwa perusahaan keluarga mempunyai permintaan yang lebih rendah untuk memilih menggunakan auditor berkualitas tinggi dibandingkan perusahaan nonkeluarga.

H2: Kontrol keluarga berpengaruh signifikan negatif terhadap pemilihan auditor. 


\subsubsection{Pengaruh Kepemilikan Keluarga Pengendali Terhadap Pemilihan Auditor \\ Adanya kepemilikan keluarga pada} sebuah perusahaan terjadi dikarenakan salah satu anggota keluarga memberikan dorongan kepada anggota keluarga lainnya untuk mengoptimalkan kekayaan seluruh pemegang saham. Sehingga sebagai akibat yang terjadi dari pengkajian tersebut mengasumsikan bahwa keluarga selaku pengawas manajer akan lebih baik daripada pemegang saham besar lainnya diluar dari anggota keluarga. Dengan demikian, dapat dikatakan karena mereka merupakan pengawas yang lebih baik, maka perusahaan yang dimiliki oleh anggota keluarga cenderung tidak menuntut layanan audit bermutu yang lebih tinggi dan bersedia membayar biaya audit yang lebih rendah dengan pilihan auditor berkualitas lebih rendah (Khan, Muttakin, \& Siddiqui, 2015).

H3: Kepemilikan keluarga pengendali berpengaruh signifikan negatif terhadap pemilihan auditor.

\subsubsection{Pengaruh Kepemilikan Asing Terhadap Pemilihan Auditor}

Pengaruh pemantauan asing pada audit eksternal dapat berbeda sesuai dengan tingkat masalah agensi antara pemegang saham dan manajer. Manajer umumnya mengetahui informasi lebih lanjut mengenai aktivitas dan kinerja manajemen perusahaan daripada pemegang saham eksternal. Diharapkan jika konflik keagenan antara pemegang saham dan manajer lebih besar, pemantau asing sebagai pemegang saham utama dan direktur eksternal akan menuntut layanan audit eksternal yang lebih tinggi untuk memeriksa kegiatan manajer (Lee, Rhee, \& Yoon, 2012). Penelitian ini juga didukung oleh Leuz, Lins, dan Warnock (2006), dalam penelitiannya dikatakan bahwa demi menghindari penanaman modal di perusahaan yang mempunyai sistem tata kelola yang buruk, terutama pada perusahaan yang berada di negara berkembang, entitas asing membutuhkan auditor berkualitas tinggi untuk menghindari kesalahan yang terjadi pada proses mengaudit.

H4: Kepemilikan asing berpengaruh signifikan positif terhadap pemilihan auditor.

\subsubsection{Pengaruh \\ Kepemilikan Manajerial Terhadap Pemilihan Auditor} Penelitian DeFond (1992) mengenai kepemilikan manajerial percaya bahwa perubahan dalam kepemilikan manajerial terkait dengan perubahan kemampuan audit untuk mengurangi konflik keagenan. Sejalan dengan penelitian milik Niskanen, Karjalainen, dan Niskanen (2010) bahwa adanya peningkatan persentase kepemilikan manajerial akan mengurangi kemungkinan pemilihan perusahaan auditor yang lebih besar. Menurut Kane dan Velury (2005), ketika tingkat kepemilikan ekuitas manajerial rendah, maka masalah keagenan yang timbul dari pemisahan kepemilikan dan kontrol akan segera meningkat. Seiring dengan meningkatkan signifikansi ekonomi untuk manajer hasil yang dipublikasikan dalam laporan keuangan publik, maka dengan adanya risiko agensi yang lebih besar, akan ada peningkatan risiko kualitas laba yang lebih rendah.

H5: Kepemilikan manajerial berpengaruh signifikan negatif terhadap pemilihan auditor.

\subsection{Variabel Kontrol}

\subsubsection{Proporsi Anggota Dewan Independen \\ Pada penelitian yang dilakukan} oleh Putra (2014), menurutnya perusahaan dengan jumlah komisaris yang lebih banyak dari suatu perusahaan maka kemungkinan besar akan memilih auditor berkualitas tinggi. Lin dan Liu (2009) menemukan hubungan positif dan signifikan antara jumlah anggota dewan pengawas dan pemilihan auditor berkualitas tinggi. Temuan ini konsisten dengan penelitian sebelumnya (Maharani, 2012; Markali \& Rudiawarni, 2012) yang menemukan 
komisaris independen secara positif mempengaruhi pilihan auditor berkualitas tinggi.

\subsubsection{Leverage}

Becker, DeFond, Jiambalvo, dan Subramanyam (1998) menunjukkan bahwa perusahaan dengan leverage tinggi memiliki kemungkinan tinggi untuk memanipulasi laba agar tidak melanggar perjanjian terhadap hutang perusahaan tersebut. Pada penelitiannya Chow dan Rise (2017) menuturkan, dengan melihat kerangka kerja agensi perusahaan maka akan menunjukkan biaya agensi meningkat sejalan dengan persentase hutang dalam struktur modal. Hal ini dapat membuka jendela bagi mekanisme pemantauan seperti halnya audit independen. Dalam penelitiannya, mendukung fakta bahwa efek leverage memerlukan pemantauan lebih lanjut yang menuntut dalam pemilihan auditor berkualitas khusus.

\subsubsection{Profitabilitas}

Johnson dan Lys (2017) mengungkapkan, bahwa return of assets menjadi salah satu faktor dalam menentukan pilihan auditor. Abbott dan Parker (2010), dimana mereka mendapatkan pengaruh positif antara profitabilitas perusahaan terhadap pemilihan auditor yang berkualitas tinggi.

\section{METODE PENELITIAN}

Penelitian ini memakai data dari laporan keuangan tahunan yang tercatat di Bursa Efek Indonesia tahun 2014-2018.

\subsection{Pemilihan Auditor}

Karim dan Zijl (2013) serta Darmadi (2016) menggunakan pengukuran pemilihan auditor dengan variabel dikotomis. Cara digunakan dalam pengukurannya ialah dengan memberi label 1 jika perusahaan menggunakan jasa audit perusahaan BIG4 dan label 0 jika entitas menggunakan jasa audit perusahaan NonBIG4.

\subsection{Konsentrasi Kepemilikan}

Darmadi (2016) menuturkan bahwa konsentrasi kepemilikan atau ditunjukkan dengan melihat proporsi terbesar saham biasa yang pemegang saham tanamkan modal dalam perusahaan terpilih tersebut. Selain Darmadi, Lin dan Liu (2009) juga menggunakan pengukuran ini.

\subsection{Kontrol Keluarga}

Dalam penelitiannya, Darmadi
(2016) menuturkan bahwa suatu perusahaan bersifat kontrol keluarga apabila perusahaan tersebut dipegang oleh individual ataupun perusahaan tertutup. Pengukuran untuk variabel dikotomis kontrol keluarga menggunakan rumus dengan memberi label 1 jika dikendalikan oleh perusahaan keluarga dan label 0 jika tidak dikendalikan oleh perusahaan keluarga.

\subsection{Kepemilikan Keluarga Pengendali \\ Selanjutnya, Darmadi (2016) juga} menggunakan variabel kepemilikan keluarga pengendali pada penelitian yang pengukurannya bersifat persentase, yaitu dengan melihat jumlah proporsi saham biasa yang dimiliki oleh keluarga pengendali perusahaan. Sama halnya dengan variabel kontrol keluarga, suatu perusahaan dikatakan memiliki kepemilikan keluarga apabila perusahaan tersebut dipegang oleh individual ataupun perusahaan tertutup.

\subsection{Kepemilikan Asing}

Untuk variabel kepemilikan asing, penulis juga menggunakan pengukuran yang dipakai oleh Darmadi (2016), dimana jika sebuah perusahaan memiliki pemegang saham dari luar negeri, maka perusahaan tersebut dapat dijadikan sampel penelitian. Data untuk pengukuran kepemilikan asing ialah dengan melihat proporsi saham biasa terbesar yang dipegang oleh perusahaan asing.

\subsection{Kepemilikan Manajerial}


Variabel ini bersifat persentase, dengan melihat jumlah saham yang dipegang oleh orang dalam perusahaan atau insider dibagi dengan jumlah saham yang beredar.

\subsection{Proporsi Anggota Dewan Independen}

Variabel proporsi anggota dewan independen dihitung dengan melihat proporsi komisaris independen pada struktur dewan komisaris perusahaan (Darmadi, 2016).

INDEP $=\frac{\text { Jumlah komisaris independen }}{\text { Jumlah anggota dewan komisaris }}$

\subsection{Leverage}

\section{HASIL PENELITIAN}

\subsection{Statistik Deskriptif}

Jenis pemakaian data yangterlibat dalam penelitian yang dilakukan ialah data sekunder dengan memakai data melalui
Niskanen, Karjalainen, dan Niskanen (2010) pada Grossman dan Hart (1982) mengemukakan bahwa leverage dapat mendorong manajer untuk menghindari keputusan jika leverage lebih tinggi dibandingkan nilai suatu keputusan tersebut. Cara pengukuran yang digunakan Darmadi (2016) ialah:

$$
\text { LEVER }=\frac{\text { Nilai buku liabilitas perusahaan }}{\text { Nilai buku aset perusahaan }}
$$

\subsection{Profitabilitas}

Salah satu penelitian yang menggunakan variabel profitabilitas ialah penelitian dari Cheng et al., (2015). Pengukuran dari Return on Assets ini didapatkan dari nilai laba bersih setelah dibagi dengan total aset perusahaan.

PROFIT $=$

Nilai laba bersih (net income) perusahaan

$$
\text { Total aset perusahaan }
$$

laporan keuangan tahunan perusahaan yang terdaftar di Bursa Efek Indonesia pada tahun 2014-2018, dimana data yang diperoleh merupakan hasil pengolahan dengan menggunakan program SPSS 22.

Tabel 1

Daftar Pemilihan Sampel

\begin{tabular}{|l|r|}
\hline \multicolumn{1}{|c|}{ Keterangan } & \multicolumn{1}{|c|}{ Jumlah } \\
\hline Perusahaan yang tercatat di BEI & 629 perusahaan \\
Perusahaan yang tidak mencukupi kriteria & (200 perusahaan) \\
Perusahaan yang dipakai sebagai sampel & 429 perusahaan \\
Jumlah tahun yang dipakai dalam penelitian & 5 tahun \\
\hline Jumlah data sampel (dikali dengan tahun) & 2145 data \\
Jumlah data outlier & (202 data) \\
Jumlah data yang digunakan untuk penelitian & 1943 data \\
\hline
\end{tabular}

Sumber: Data diolah penulis, 2020.

Tabel 2

Hasil Uji Statistik Deskriptif

\begin{tabular}{|l|c|c|c|c|}
\hline \multicolumn{1}{|c|}{ Variabel } & Min & Maks & Mean & Std. Deviasi \\
\hline OWNCON & 0.0142 & 0.9850 & 0.5057 & 0.2102 \\
FAMOWN & 0.0000 & 0.9850 & 0.2243 & 0.2861 \\
FOROWN & 0.0000 & 0.8508 & 0.1083 & 0.2174 \\
MANOWN & 0.0000 & 0.3801 & 0.0222 & 0.0627 \\
INDEP & 0.1429 & 0.7500 & 0.4137 & 0.1081 \\
LEVER & 0.0002 & 1.9475 & 0.5197 & 0.2644 \\
PROFIT & -0.4363 & 0.4579 & 0.0292 & 0.0868 \\
\hline
\end{tabular}

Sumber: Data diolah penulis, 2020.

Jika melihat hasil pengamatan memperlihatkan variabel konsentrasi terhadap Tabel 2 di atas, tabel kepemilikan memiliki skala minimum 
sebesar 0.0142, dimana menunjukkan terdapat perusahaan yang mempunyai tingkat kepemilikan terbesar hanya sebesar $1.42 \%$ dan perusahaan tersebut ialah PT Bakrie Sumatera Plantations Tbk di tahun 2015, sementara itu skala maksimum dimiliki oleh PT Majapahit Inti Corpora Tbk pada tahun 2018 ialah sebesar 0.9850 atau suatu entitas memilih untuk berkonsentrasi menanamkan modalnya pada satu perusahaan tersebut sebesar $98.50 \%$. Rata-rata yang dimiliki variabel konsentrasi kepemilikan ialah 0.5057 dengan standar deviasi atau data persebaran yang dimiliki ialah sebesar 0.2102.

Variabel kepemilikan keluarga pengendali mempunyai skala minimum 0.0000 yang menunjukkan terdapat beberapa perusahaan tercatat yang dikendalikan oleh perusahaan yang bersifat non-keluarga, sedangkan untuk skala maksimum sebesar 0.9850 yang menunjukkan sebaliknya, yakni terdapat suatu perusahaan yang modal saham tertingginya dipegang oleh perusahaan lain yang bersifat keluarga sebesar $98.50 \%$ dan perusahaan tersebut ialah PT Majapahit Inti Corpora Tbk di tahun 2018. Variabel kepemilikan keluarga pengendali juga memiliki skala rata-rata 0.2243 dan standar deviasi sebesar 0.2861.

Kepemilikan asing mempunyai skala minimum sebesar 0.0000 , sama halnya dengan variabel kepemilikan keluarga pengendali, hal ini menunjukkan bahwa adanya beberapa perusahaan di Bursa Efek Indonesia yang modal sahamnya tidak dimiliki oleh entitas asing. Sementara itu untuk skala maksimum yang dimiliki kepemilikan asing sebesar 0.8508 atau $85.08 \%$ yang dipegang oleh PT Bank OCBC NISP Tbk dari tahun 2014 hingga 2018, yang menyatakan bahwa selama lima tahun tersebut, entitas asing menanamkan 85.08\% modalnya pada PT Bank OCBC NISP. Skala rata-rata yang dipunyai oleh variabel kepemilikan asing ialah sebesar 0.1083 dan skala standar deviasi sebesar 0.2174 .
Untuk variabel independen terakhir dari penelitian ini, skala minimum untuk variabel kepemilikan manajerial ialah sebesar 0.0000 , dimana modal dasar suatu perusahaan tersebut tidak ada dipegang oleh para dewan perusahaan itu sendiri. Kemudian untuk skala maksimum yang dimiliki ialah sebesar 0.3801 atau $38.01 \%$ yang dipegang oleh PT Wismilak Inti Makmur Tbk pada tahun 2017 dan 2018. Selanjutnya, variabel kepemilikan manajerial memiliki skala rata-rata 0.0222 dan standar deviasi yang dimiliki sebesar 0.0627 .

Untuk variabel kontrol pertama ialah variabel proporsi anggota dewan independen memiliki nilai minimum sejumlah 0.1429, dimana pada perusahaan PT Total Bangun Persada Tbk tahun 20142016 memiliki hanya satu komisaris independen dari tujuh dewan komisaris. Sementara itu nilai maksimum yang didapati ialah berupa 0.7500 , dimana terdapat beberapa perusahaan yang memiliki tiga komisaris independen dari empat anggota dewan komisarisnya. Nilai rata-rata yang dimiliki variabel proporsi anggota dewan independen ialah 0.4137 dan standar deviasi ialah sebesar 0.1081.

Pada variabel leverage, nilai minimum yang didapatkan ialah sejumlah 0.0002 dimana rasio ini dipegang oleh perusahaan PT Indoritel Makmur Internasional Tbk pada tahun 2014. Sementara itu untuk nilai maksimum, angka yang didapatkan ialah sejumlah 1.9475 dan dipegang oleh perusahaan PT Primarindo Asia Infrastructure Tbk di tahun 2017. Pada variabel leverage ini juga, nilai rata-rata yang dimilikinya ialah sejumlah 0.5197 dan standar deviasi yang dimiliki ialah sejumlah 0.2644 .

Untuk variabel kontrol terakhir yang terlibat dalam penelitian ini, nilai minimum dari variabel profitabilitas ialah sebesar 0.4363 yang dimiliki oleh perusahaan PT Gozco Plantations Tbk pada tahun 2016 dan nilai maksimum sebesar 0.4579 dipegang oleh PT Matahari Department Store Tbk pada tahun 2015. Sementara itu untuk nilai 
rata-rata ialah berukuran 0.0292 dan nilai standar deviasi yang dimiliki ialah sebesar 0.0868 .

Tabel 3

Hasil Uji Statistik Deskriptif Variabel Independen Dummy

\begin{tabular}{|l|c|c|c|c|}
\hline & Frekuensi & Persen & Persen Valid & Persen Kumulatif \\
\hline NON-FAMCON & 1069 & 55.0 & 55.0 & 55.0 \\
FAMCON & 874 & 45.0 & 45.0 & 100.0 \\
Total & 1943 & 100.0 & 100.0 & \\
\hline
\end{tabular}

Sumber: Data diolah penulis, 2020.

Menurut hasil uji variabel kontrol keluarga, sebagai variabel indepen yang berbentuk dummy, menunjukkan dari 1943 data sampel yang digunakan terdapat 1059 data sampel atau sebesar $55.0 \%$ data yang bersifat non-family control, dimana suatu data tersebut perusahaannya tidak dikendalikan oleh perusahaan lain yang bersifat keluarga, sedangkan 874 data lainnya atau sebanyak $45.0 \%$ terbukti dikendalikan oleh perusahaan lain yang bersifat keluarga.

Tabel 4

Hasil Uji Statistik Deskriptif Variabel Dependen Dummy

\begin{tabular}{|l|c|c|c|c|}
\hline & Frekuensi & Persen & Persen Valid & Persen Kumulatif \\
\hline NON-BIG4 & 1143 & 58.8 & 58.8 & 58.8 \\
BIG4 & 800 & 41.2 & 41.2 & 100.0 \\
Total & 1943 & 100.0 & 100.0 & \\
\hline
\end{tabular}

Sumber: Data diolah penulis, 2020.

Hasil uji variabel pemilihan auditor sebagai variabel dependen yang berbentuk dummy, menunjukkan dari 1943 data sampel yang digunakan terdapat 800 data sampel atau $41.2 \%$ yang mengunakan salah satu jasa auditor dari perusahaan BIG4 entah dari PricewaterhouseCoopers, Deloitte Touche Tohmatsu, Ernst \& Young, atau KPMG, sedangkan 1143 data sampel atau $58.8 \%$ lainnya memilih untuk menggunakan jasa auditor dari perusahaan Non-BIG4, sehingga kesimpulan yang didapatkan berupa perusahaan terbuka yang terdaftar dalam BEI lebih besar jumlahnya menggunakan jasa auditor NonBIG4.

\subsection{Uji Multikolinieritas}

Guna dilakukannya uji multikolinieritas dalam penelitian ialah untuk melihat apakah ada kolerasi antarvariabel bebas dalam model regresi. Jika menunjukkan skala VIF yang lebih kecil dari 10 dan skala tolerance lebih besar dari 0.10 , maka dapat dinyatakan bahwa data yang berkaitan tidak mengalami multikorelasi. Berikut ialah tabel dari hasil uji multikolinieritas:

Tabel 5 
Hasil Uji Multikolinieritas

\begin{tabular}{|l|c|c|c|}
\hline \multicolumn{1}{|c|}{ Keterangan } & Tolerance & VIF & Kesimpulan \\
\hline OWNCON & 0.5910 & 1.6910 & Terlepas dari multikolerasi \\
FAMCON & 0.1970 & 5.0810 & Terlepas dari multikolerasi \\
\hline FAMOWN & 0.1600 & 6.2510 & Terlepas dari multikolerasi \\
FOROWN & 0.8310 & 1.2030 & Terlepas dari multikolerasi \\
MANOWN & 0.9520 & 1.0500 & Terlepas dari multikolerasi \\
INDEP & 0.9680 & 1.0330 & Terlepas dari multikolerasi \\
LEVER & 0.8780 & 1.1390 & Terlepas dari multikolerasi \\
PROFIT & 0.8980 & 1.1130 & Terlepas dari multikolerasi \\
\hline
\end{tabular}

Sumber: Data diolah penulis, 2020.

\subsection{Uji Nagelkerke R Square}

Hasil percobaan determinasi yang dilakukan memperlihatkan bahwa nilai nagelkerke $\mathrm{R}$ square yang didapatkan ialah 0.1920 , yang mana memiliki arti sebesar
$19.20 \%$ ketepatan variabel independen dalam menjelaskan variabel pemilihan auditor dalam observasi ini, sementara $80.80 \%$ lainnya dijelaskan mengunakan variabel lain.

Tabel 6

Hasil Uji Nagelkerke R Square

\begin{tabular}{|c|c|c|c|}
\hline Step & $\mathbf{- 2 ~ L o g ~ l i k e l i h o o d}$ & Cox \& Snell R Square & Nagelkerke R Square \\
\hline 1 & $2333.530^{\mathrm{a}}$ & 0.1430 & 0.1920 \\
\hline
\end{tabular}

Sumber: Data diolah penulis, 2020.

\subsection{Uji Hosmer and Lemeshow}

Hasil pengujian kepantasan model regresi yang didapatkan melalui uji hosmer and lemeshow ialah sejumlah 0.1300 atau $13 \%$, mengingat hasil uji dapat dikatakan signifikan apabila nilai yang didapat ialah lebih besar dari 0.05 , sehingga dapat disimpulkan bahwa hasil uji menunjukkan metode regresi logistik yang dipakai tidak mampu memprediksi hasil variabel dengan sempurna dan sesuai dengan model.

Tabel 7

Hasil Uji Hosmer and Lemeshow

\begin{tabular}{|c|c|c|c|}
\hline Step & Chi-square & Df & Sig. \\
\hline 1 & 12.4950 & 8 & 0.1300 \\
\hline
\end{tabular}

Sumber: Data diolah penulis, 2020.

\subsection{Uji Wald}

Dilaksanakannya uji wald bertujuan untuk melihat signifikansi dampak variabel independen yang ada terhadap variabel dependen. Hasil dari pengujian inilah yang nantinya menunjukkan terbukti atau tidak terbukti sebuah hipotesis yang ingin dilakukan penelitian.

Tabel 6

Hasil Uji Wald

\begin{tabular}{|l|c|c|c|c|}
\hline \multicolumn{1}{|c|}{ Variabel } & $\boldsymbol{B}$ & Sig. & Kesimpulan & Hipotesis \\
\hline OWNCON & 2.6650 & 0.0000 & Signifikan positif & Diterima \\
FAMCON & -0.7400 & 0.0010 & Signifikan negatif & Diterima \\
FAMOWN & -2.3640 & 0.0000 & Signifikan negatif & Diterima \\
FOROWN & 1.3650 & 0.0000 & Signifikan positif & Diterima \\
MANOWN & 1.0820 & 0.1780 & Tidak signifikan & Ditolak \\
\hline
\end{tabular}

Sumber: Data diolah penulis, 2020. 
Berdasarkan hasil percobaan hipotesis, didapat nilai signifikansi untuk variabel konsentrasi kepemilikan senilai 0.0000 yang berarti variabel ini berdampak secara positif terhadap variabel dependen pemilihan auditor dengan demikian $\mathrm{H}_{1}$ dapat diterima. Dari hasil ini menguatkan teori-teori yang sebelumnya bahwa jika suatu kepemilikan terkonsentrasi kepada suatu entitas maka agency cost dari perusahaan tersebut akan tinggi, karena jelas suatu entitas yang memegang saham terbesar itu tidak ingin terjadi bias informasi dari manajemen yang menyebabkan fraud pada perusahaan tersebut Penelitian yang dilakukan oleh Zeng (2013), Farooq dan El Kacemi (2011), Dwekat dan Mardawi (2017), dan N. Houqe, van Zijl, Dunstan, dan Karim (2010) juga mendapatkan hasil yang signifikan, sedangkan penelitian yang dikerjakan oleh Wan Nasrudin, Mohamed, dan Shafie (2017), dan Imanzadeh dan Lalepour (2013) mendapatkan hasil yang bertentangan yaitu variabel konsentrasi kepemilikan secara signifikan tidak berdampak positif pada pemilihan auditor.

Untuk variabel kontrol keluarga, didapatkan skala signifikansi sebesar 0.0010 atau angka kurang dari 0.05 sehingga hal ini membuat kontrol keluarga berdampak signifikan secara negatif kepada variabel pemilihan auditor. Dapat disimpulkan variabel kontrol keluarga menerima $\mathrm{H}_{2}$. Menurut Francis et al. (2009) pada studinya berpendapat bahwa pemilihan auditor berkualitas dapat didorong oleh kendala keagenan demi kebutuhan yang efektivitas dan efisiensi organisasi, sehingga apabila suatu perusahaan dikontrol oleh organisasi yang bersifat keluarga maka kendala keagenan yang terjadi pada perusahaan tersebut akan semakin kecil dikarenakan operasi pada perusahaan tersebut lebih memegang prinsip kepercayaan, maka dari pada itu kebutuhan dalam memilih auditor yang berkualitas sangat rendah saat dipegang oleh perusahaan lain yang bersifat keluarga. Hasil uji yang diperoleh sama dengan penelitian yang dilakukan El-Ghoul, Guedhami, Lennox, dan Pittman (2013); Francis, Richard, dan Vanstraelen (2009); Ianniello et al. (2015).

Untuk variabel kepemilikan keluarga pengendali, didapatkan nilai signifikansi sebesar 0.0000 , maka dari itu hasil uji wald variabel ini menunjukkan adanya pengaruh signifikan berbentuk negatif antara kepemilikan keluarga pengendali dengan pemilihan auditor. Terdapat beberapa penelitian yang mendapatkan hasil yang serupa, diantara lainnya ialah penelitian dari Dey, Hoi, dan Robin (2011); Ho dan Kang (2013). Berbeda halnya dengan penelitian dari Cho dan Wu (2014) serta Niskanen et al. (2011b) yang mendapatkan hasil signifikan positif terhadap pemilihan auditor.

Hasil uji wald variabel kepemilikan asing menerangkan nilai signifikansi sebesar 0.0000 , hal ini membuat hipotesis keempat terbukti maka kepemilikan asing berdampak secara signifikan positif kepada pemilihan auditor. Apabila saham suatu perusahaan dimiliki oleh entitas asing maka kinerja perusahaan tersebut akan semakin membaik, karena entitas asing mempunyai sistem manajemen dan keahlian yang cukup baik sehingga akan berdampak positif untuk perusahaan tempat pihak asing itu mnginvestasikan sahamnya. Terdapat beberapa studi yang mendapatkan hasil yang sama diantaranya studi milik Azibi, Tondeur, \& Rajhi (2010), Pouraghaja, Yadollahzadeh, \& Haghparast (2013), Zureigat (2011), Lee et al. (2018), dan Shan (2014).

Untuk variabel kepemilikan manajerial didapatkan nilai signifikansi sejumlah 0.1610 sehingga disimpulkan bahwa kepemilikan manajerial tidak memiliki dampak terhadap pemilihan auditor. Piot (2001) yang menegaskan tidak terdapat relasi antara kepemilikan manajerial dan keputusan dalam memilih auditor dengan kualitas lebih tinggi untuk perusahaan terdaftar yang dipertimbangkan dalam penelitian ini. Bahkan, teori agensi menyarankan manajer untuk berperilaku 
oportunistik dalam memaksimalkan kekayaan mereka. Karena kualitas audit dipandang sebagai kendala untuk perilaku tersebut, maka manajer tidak memiliki insentif untuk memilih auditor berkualitas lebih tinggi. Terdapat penelitian yang mendapatkan hasil uji wald yang sama untuk variabel ini, yaitu Soliman dan Elsalam (2013). Tetapi lain halnya dengan penelitian dari Mahdavi et al., (2011) dan Dwekat dan Mardawi (2017) yang mendapatkan hasil uji variabel kepemilikan manajerial memberi dampak secara signifikan positif terhadap pemilihan auditor.

\section{KESIMPULAN}

\subsection{Kesimpulan}

Penelitian mengenai tata kelola pada perusahaan terdaftar di BEI dilaksanakan dengan menyangkut tujuan untuk menganalisis dampak yang terjadi terhadap pemilihan auditor. Berikut ialah kesimpulan yang didapatkan dari masing-masing hipotesis:

H1: Hipotesis ini diterima. Nilai signifikansi untuk variabel konsentrasi kepemilikan senilai 0.0000. Hasil ini menguatkan teori-teori yang sebelumnya bahwa jika suatu kepemilikan terkonsentrasi kepada suatu entitas maka agency cost dari perusahaan tersebut akan tinggi.

H2: Hipotesis ini diterima. Kontrol keluarga berpengaruh signifikan negatif terhadap pemilihan auditor. Variabel kontrol keluarga, didapatkan skala signifikansi sebesar 0.0010 atau angka kurang dari 0.05 .

H3: Hipotesis ini diterima. Variabel kepemilikan keluarga pengendali, didapatkan nilai signifikansi sebesar 0.0000 atau lebih besar dari 0.05. Pemilihan auditor berkualitas dapat didorong oleh kendala keagenan demi kebutuhan yang efektivitas dan efisiensi organisasi, sehingga apabila suatu perusahaan dikontrol oleh organisasi yang bersifat keluarga maka kendala keagenan yang terjadi pada perusahaan tersebut akan semakin kecil.
H4: Hipotesis ini diterima. Variabel kepemilikan asing menerangkan nilai signifikansi sebesar 0.0000. Apabila saham suatu perusahaan dimiliki oleh entitas asing maka kinerja perusahaan tersebut akan semakin membaik.

H5: Hipotesis ini ditolak. Variabel kepemilikan manajerial didapatkan nilai signifikansi sejumlah 0.1610 . Tidak terdapat relasi antara kepemilikan manajerial dan keputusan dalam memilih auditor dengan kualitas lebih tinggi.

\subsection{Keterbatasan}

Ketika sedang melaksanakan penelitian ini, penulis menemukan adanya keterbatasan-keterbatasan terkait yang terjadi, antara lain:

1. Objek penelitian memiliki keterbatasan dikarenakan penulis hanya memakai perusahaan-perusahaan tercatat di BEI, maka dari itu hasil analisis yang diperoleh tidak bisa dibandingkan.

2. Dari 629 entitas yang tercatat di BEI, banyak diantaranya tidak mengeluarkan baik laporan tahunan maupun laporan keuangan secara menyeluruh selama periode yang dibutuhkan untuk penelitian ini yaitu 20142018, sehingga hal ini membuat kendala bagi peneliti untuk mengumpulkan laporan keuangan secara lengkap dalam hal sampel.

\subsection{Rekomendasi}

Dalam hal ini peneliti memberikan beberapa rekomendasi demi penelitian seterusnya, yaitu:

1. Memakai sampel perusahaan dari negara lain agar temuan dari penelitian dapat dibandingkan dengan penelitian yang memakai sampel perusahaan di Indonesia.

2. Untuk perusahaan yang tercatat di BEI, diharapkan untuk mengunggah laporan keuangan maupun laporan tahunan yang teraudit secara lengkap agar penelitian selanjutkan dapat dilakukan dengan baik dan efisien. 
3. Mengembangkan

atau menggunakan variabel lainnya yang dapat memperngaruhi pemilihan auditor.

\section{DAFTAR PUSTAKA}

Abbott, L. ., \& Parker, S. (2010). Audit Committee Characteristics and Auditor Selection. A Journal of Practice and Theory, 19((2)), 47-66.

Azibi, J., Tondeur, H., \& Rajhi, M. T. (2010). Auditor choice and institutional investor characteristics after the Enron scandal in the French context. International Journal of Economics and Accounting.

Becker, C. ., DeFond, M. L., Jiambalvo, J., \& Subramanyam, K. R. (1998). The effect of audit quality on earning management. In Contemporary Accounting Research (Vol. 15).

Cheng, C. L., Hsu, C. S., \& Kung, F. H. (2015). Political connections, managerial incentives and auditor choice: evidence from China. Pacific Accounting Review, 27(4), 441-465.

Cho, C. C., \& Wu, C. H. (2014). Role of auditor in agency conflict and corporate governance: Empirical analyses of Taiwanese firms. Chinese Management Studies, 8(3), 333-353.

Chow, C. W., \& Rise, S. J. (2017). Qualified Audit Opinions and Auditor Switching. The Accounting Review, 326-335.

Corten, M., Steijvers, T., \& Lybaert, N. (2017). The effect of intrafamily agency conflicts on audit demand in private family firms: The moderating role of the board of directors. Journal of Family Business Strategy, 8(1), 13-28.

Darmadi, S. (2016). Ownership concentration, family control, and auditor choice: Evidence from an emerging market. Asian Review of Accounting, 24(1), 19-42.

DeFond, M. L. (1992). The associations between changes in client firm agency cost and auditor switching. Auditing: A Journal of Practice \& Theory, 11((1)), 16-31.

Dey, R. M., Hoi, C. K., \& Robin, A. (2011). Family Firms and Auditor Choice: A Focus on IPO Firms.

Dwekat, A., \& Mardawi, Z. (2017). Corporate Governance Practices and Audit Quality: An Empirical Evidence of the companies listed in Palestine Exchange (PEX).
(March).

El Ghoul, S., Guedhami, O., Lennox, C. S., \& Pittman, J. A. (2009). External versus Internal Monitoring: The Importance of Multiple Large Shareholders and Families to Auditor Choice in Western European Firms. SSRN Electronic Journal.

Farooq, O., \& El Kacemi, Y. (2011). Ownership Concentration, Choice of Auditors, and Firm Performance: Evidence from the MENA Region. Review of Middle East Economics and Finance, 7(2), 1-17.

Farooq, O., \& Tabine, S. (2015). Agency Problems and the Choice of Auditors: Evidence from the MENA Region. Review of Middle East Economics and Finance, 11(1), 79-97.

Francis, J. R., Richard, C., \& Vanstraelen, A. (2009). Assessing France's joint audit requirement: Are two heads better than one? Auditing, 28(2), 35-63.

Grossman, S. J., \& Hart, O. D. (1982). Corporate Financial Structure and Managerial Incentives.

Hall, C. M., Hoffman, B. W., \& Liu, Z. (2017). Ownership Structure and the Demand for Auditor Quality. SSRN Electronic Journal, $1,1-18$.

Ho, J. L. Y., \& Kang, F. (2013). Auditor choice and audit fees in family firms: Evidence from the S\&P 1500. Auditing: A Journal of Practice \& Theory, 32(4), 71-93.

Houqe, N., van Zijl, T., Dunstan, K. L., \& Karim, A. K. M. W. (2010). Board Ethics and Auditor Choice - International Evidence. SSRN Electronic Journal, 1-31.

Ianniello, G., Mainardi, M., \& Rossi, F. (2015). Family control , corporate governance , and auditor choice: evidence from Italy. Journal of Accounting and Finance, 5(2), 99-116.

Imanzadeh, P., \& Lalepour, M. (2013). The effect of corporate governance mechanisms on auditing quality of firms accepted in Tehran Stock Exchange. Applied Mathematics in Engineering, Management and Technology, 1(3), 5863.

Johnson, W. B., \& Lys, T. (2017). The market for audit services: Evidences from voluntary auditor changes. Journal of Accounting and Economics.

Kane, G. D., \& Velury, U. (2005). The Impact of Managerial Ownership on the Likelihood of Provision of High Quality 
Auditing Services. Review of Accounting and Finance, 4(2), 86-106.

Karim, A. W., \& Zijl, T. van. (2013). Efficiency and opportunism in auditor quality choice in emerging audit services markets. International Journal of Accounting \& Information Management, 21(3), 241-256.

Khan, A., Muttakin, M. B., \& Siddiqui, J. (2015). Audit fees, auditor choice and stakeholder influence: Evidence from a family-firm dominated economy. British Accounting Review, 47(3), 304-320.

Knechel, W. R., Niemi, L., \& Sundgren, S. (2005). Determinants of Auditor Choice: Evidence from a Small Client Market.

Kolsi, M. C., Makni, I., \& Affes, H. (2012). The Impact of Corporate Governance Mechanisms on Audit Quality: Evidence from Tunisia. The IUP Journal of Corporate Governance, 11(3).

Lee, S. C., Rhee, M., \& Yoon, J. (2012). The Effects of Foreign Monitoring on Audit Quality: Evidence from Korea. Ssrn, 1-35.

Lee, S. C., Rhee, M., \& Yoon, J. (2018). Foreign Monitoring and Audit Quality: Evidence from Korea. Ssrn, 1-22.

Leuz, C., Lins, K. V., \& Warnock, F. E. (2006). Do Foreigners Invest Less In Poorly Governed Firms? 14(1), 3.

Lin, Z. J., \& Liu, M. (2009). The impact of corporate governance on auditor choice: Evidence from China. Journal of International Accounting, Auditing and Taxation, 18(1), 44-59.

Maharani, D. (2012). The effect of corporate governance mechanism on auditor choice. Banjarmasin, Indonesia: Lambung Mangkurat University.

Mahdavi, G., Maharlouie, M., Ebrahimi, F., \& Sarikhani, M. (2011). The Impact of Corporate Governance on Auditor Choice. SSRN Electronic Journal, (68).

Markali, O. E., \& Rudiawarni, F. . (2012). The relationship of corporate governance mechanisms and the auditor choice of financial industries. Jurnal Ilmiah Mahasiswa Universitas Surabaya, 1(1), 114.

Matonti, G., Tucker, J., \& Tommasetti, A. (2016). Auditor choice in Italian non-listed firms. Managerial Auditing Journal, 31(45), 458-

Nasrudin, W. A. W., Mohamed, N., \& Shafie, N. A. (2017). Corporate Governance \&amp; Auditor Choice in Malaysia. SHS Web of Conferences, 36, 00007.

Niskanen, M., Karjalainen, J., \& Niskanen, J. (2010). The Role of Auditing in Small, Private Family Firms: Is It About Quality and Credibility? Family Business Review, 23(3), 230-245.

Niskanen, M., Karjalainen, J., \& Niskanen, T. (2011). Audit Quality: The Role of Board Structure in Family Firms. Journal of Strategic Studies, 34(2), 28.

PSAK. (2018). Standar Akuntansi Keuangan (I. A. Indonesia, ed.). Jakarta.

Putra, D. (2014). the Influence of Corporate Governance Mechanisms Toward External Auditor Choice (Seminar Bi). Bandar Lampung, Indonesia: IBI Darmajaya.

Revier, E., \& Schroé, R. (2010). DETERMINANTS OF AUDITOR CHOICE.

Shan, Y. G. (2014). The impact of internal governance mechanisms on audit quality: a study of large listed companies in China. Nternational Journal of Accounting, Auditing and Performance Evaluation, 10(1), 68-90.

Soliman, M. S., \& Elsalam, M. A. (2013). Corporate Governance Practices and Audit Quality: An Empirical Study of the Listed Companies in Egypt. SSRN Electronic Journal, 71(2), 1292-1297.

Trisnawati, I. T. A. (2015). Faktor Determinan Pemilihan Auditor. 17(2), 112-124.

Yuniarti, R. (2011). Audit Firm Size, Audit Fee and Audit Quality. Jounal of Global Management, 2(1).

Zeng, Y. (2013). Is Corporate Governance A Determinant of Auditor Choice? Evidence From Turkey. EGE Academic Review, 13(2), 273-284.

Zureigat, Q. M. (2011). The Effect of Ownership Structure on Audit Quality: Evidence from Jordan. International Journal of Business and Social Science, 2(10), 38-46. 